\title{
Pengaruh Pendidikan, Pelatihan dan Penyuluhan Terhadap Partisipasi Anggota Koperasi Pondok Pesantren
}

\author{
Agus Eko Sujianto \\ Dosen Sekolab Tinggi Agama Islam Negeri (STAIN) Tulungagung \\ ae_stainta@yaboo.co.id
}

\begin{abstract}
The purposes of this research are intended to measure the influence of education, Training and counseling simultaneously to the member participation of Koperasi Pondok Pesantren (Koppontren). Qualitative method was applied with the cross-section model. In organizing 320 person of respondent the writer applied multistage random sampling and each variable were measured with linear programming. Finally the finding of the research shows that education, training, and counseling simultaneously influence the members of Koppotren in Tulungagung regency.
\end{abstract}

Keywords: Education, Training, Counseling

\begin{abstract}
Abstrak
Tujuan penelitian ini menguji: (1) pengarub pendidikan terbadap partisipasi anggota; (2) pengarub pelatihan terbadap partisipasi anggota; (3) pengarub penyuluhan terhadap partisipasi anggota dan (4) pengarub pendidikan, pelatihan dan penyuluban secara simultan terbadap partipasi anggota Koperasi Pondok Pesantren (Koppontren). Metode penelitian menggunakan pendekatan kuantitatif dengan desain penelitian model cross-sectional. Teknikpenarikan sampel menggunakan acak bertingkat (Multistage Random Sampling) sebingga diperoleh sampel sebanyak 320 orang yang selanjutnya merupakan responden penelitian. Pengujian pengarub variabel-variabel penelitian menggunakan regresi linear berganda, dimana data penelitian diolah dengan SPSS versi 19. Temuan penelitian menunjukkan babwa: (1) pendidikan berpengarub signifikan terhadap partisipasi anggota; (2) pelatiban berpengarub signifikan terhadap partisipasi anggota; (3) penyuluban berpengarub signifikan terhadap partisipasi anggota serta
\end{abstract}


(4) pendidikan, pelatihan dan penyuluban secara simultan berpengaruh signifikan terhadap partipasi anggota Koppontren di Kabupaten Tulungagung.

Kata Kunci: Pendidikan, Pelatihan, Konseling

\section{Pendahuluan}

Sebagai salah satu lembaga pendidikan nonformal, keberadaan Pondok Pesantren (Pontren) menjadi pilar utama menjaga moral dan keberadaban bangsa serta warga negaranya. Moral dan keberadaban ini tidaklah datang dengan sendirinya melainkan dapat ditemukan melalui proses pembelajaran yang terencana, berkelanjutan, berakar pada nilai-nilai agama, kebudayaan nasional Indonesia dan tanggap terhadap tuntutan perubahan zaman.

Selanjutnya Undang-Undang Sistem Pendidikan Nasional nomor 20 tahun 2003 mendeskripsikan bahwa pendidikan nasional berfungsi mengembangkan kemampuan dan membentuk watak serta peradaban bangsa yang bermartabat dalam rangka mencerdaskan kehidupan bangsa, bertujuan untuk berkembangnya potensi peserta didik agar menjadi manusia yang beriman dan bertakwa kepada Tuhan Yang Maha Esa, berakhlak mulia, sehat, berilmu, cakap, kreatif, mandiri, dan menjadi warga negara yang demokratis serta bertanggung jawab.

Fungsi pendidikan nasional tersebut sangat relevan dengan tujuan pendidikan Islam sebagaimana firman Allah SWT dalam QS al Qashash: 77, yaitu tujuan yang berorientasi ukhrawi, bahwa seorang hamba agar melakukan kewajiban kepada Allah SWT serta tujuan yang berorientrasi duniawi untuk membentuk manusia agar mampu menghadapi segala bentuk kehidupan.

Untuk membentuk manusia agar mampu menghadapi segala bentuk kehidupan inilah yang menjadi peluang Koperasi Pondok Pesantren (Koppontren) berkembang dan hidup di lingkungan Pontren, mengingat keberadaan Pontren yang masih diragukan sebagai lembaga ideal untuk mencetak generasi muda yang berkualitas. Padahal di era global dengan persaingan ketat dewasa ini, membangun sumber daya manusia (SDM) tidaklah cukup dengan mem- 
bentuk budi pekerti saja, melainkan diperlukan pula berbagai pengetahuan dan keterampilan (skill) yang selama ini masih kurang mampu dipenuhi oleh Pontren.

Koppontren sebagai salah satu jenis koperasi yang berasal dari anggota dan dinikmati oleh anggota, maka dalam operasionalnya dikendalikan oleh anggota. Koppontren dibentuk karena terdapat kebutuhan yang sama para santri, dengan demikian partisipasi mereka sangat diharapkan dan merupakan "ruh" atau jiwa dalam berkoperasi. Partisipasi anggota harus dipupuk untuk mewujudkan perekonomian yang sesuai dengan cita-cita luhur sebagaimana dideskripsikan dalam UUD 1945 pasal 33 ayat 1 bahwa, perekonomian disusun sebagai usaha bersama berdasar atas asas kekeluargaan serta Pembukaan UUD 1945 untuk memajukan kesejahteraan umum.

Penelitian ini dilakukan pada Koppontren mengingat Pontren sebagai tempat bernaungnya lembaga ini masih memiliki keterbatasan-keterbatasan (Amir, 2006:57) antara lain: (1) SDM. Sekalipun SDM dalam bidang keagamaan tidak dapat diragukan lagi, tetapi dalam rangka meningkatkan eksistensi dan peranan Pontren dalam bidang kehidupan sosial masyarakat diperlukan perhatian yang serius. Penyediaan dan peningkatan sumber daya manusia dalam bidang manajemen kelembagaan, serta bidang-bidang yang berkaitan dengan kehidupan sosial masyarakat perlu menjadi pertimbangan Pontren; (2) kemandirian ekonomi kelembagaan. Kebutuhan keuangan selalu menjadi kendala dalam melakukan aktivitas Pontren, baik yang berkaitan dengan kebutuhan pengembangan Pontren maupun dalam proses aktivitas keseharian Pontren. Tidak sedikit proses pembangunan Pontren berjalan dalam waktu lama yang hanya menunggu sumbangan atau donasi dari pihak luar, bahkan harus melakukan penggalangan dana di pinggir jalan dan (3) kurikulum yang berorientasi life skills santri dan masyarakat. Pontren masih berkonsentrasi pada peningkatan wawasan dan pengalaman keagamaan santri dan masyarakat. Apabila melihat tantangan kedepan yang semakin berat, peningkatan kapasitas santri dan masyarakat tidak hanya cukup dalam bidang keagamaan semata, tetapi harus ditunjang oleh kemampuan yang bersifat keahlian.

Keterbatasan-keterbatasan di atas dapat dirubah menjadi peluang jika keberadaan Koppontren benar-benar dibangun atas 
dasar kebutuhan yang sama para anggotanya. Dunn dalam Gray dan Butler (1991:82-93) menjelaskan, koperasi mengorangkan anggota dalam arti anggota dituntut untuk tidak pasif melainkan aktif berperan berdasar tiga prinsip sebagai pengguna-pemilik, pengguna-pengendali dan pengguna-pemikat. Sebagai pemikat karena koperasi juga melayani masyarakat bukan anggota.

Diharapkan dengan aktifnya anggota dapat menjadi pemikat pengguna bukan anggota sesuai dengan sifat kegiatan usahanya. Sedangkan Salim (2008:28) mendeskripsikan bahwa, peran aktif anggota sebagai pemilik-pengguna, pengendali-pengguna dan pengguna-pemikat dalam praktik merupakan wujud partisipasi anggota sebagai pencerminan adanya pemberdayaan koperasi. Zeuli dan Cropp (1980:7) mendefinisikan bahwa, koperasi adalah pengguna-pemilik, pengguna-pengendali dan pendistribusian SHU secara proporsional.

Berdasar hasil observasi lapangan, untuk membangun partisipasi anggota bukanlah pekerjaan yang mudah. Direktorat Jenderal Koperasi (1980:33) mendeskripsikan, diperlukan pembinaan perkoperasian kepada anggota yang diharapkan dapat meningkatkan kuantitas dan kualitas anggota. Cara pembinaan untuk meningkatkan kuantitas anggota antara lain dengan melakukan penerangan dan penyuluhan kepada masyarakat. Sedangkan pembinaan untuk meningkatkan kualitas anggota antara lain dengan mengaktifkan pertemuan-pertemuan untuk berdiskusi atau berdialog serta menyelenggarakan pendidikan dan pelatihan bagi anggota dan calon anggota.

Fokus bahasan terkait dengan pembinaan anggota dalam studi ini yaitu: (1) pendidikan; (2) pelatihan dan (3) penyuluhan yang merujuk pendapatan Nirbito (2001:43), Mathis dan Jackson (2006:18) serta Robbins (2003:33). Pendidikan terkait dengan pengetahuan, yaitu menanamkan informasi kognitif (Mathis dan Jackson, 2006:24) kepada anggota. Bentuk dari pendidikan ini merujuk pada domain kognisi yang dikemukakan oleh Bloom (1956) yaitu: (1) tingkat pengetahuan (knowledge); (2) tingkat pemahaman (comprehension); (3) tingkat penerapan (application); (4) tingkat analisis (analysis); (5) tingkat sintesis (synthesis) dan (6) tingkat evaluasi (evaluation). 
Pelatihan ditujukan untuk memberikan keterampilan maksimum kepada peserta (Mathis dan Jackson, 2006:22), yaitu dalam bentuk (Robbins, 2003:56): (1) menawarkan model untuk merebut perhatian yang dilatih; (2) memberikan sifat-sifat motivasional; (3) membantu yang dilatih agar membekas apa yang telah dipelajari untuk digunakan kelak dan (4) memberikan kesempatan untuk mempraktikkan perilaku baru. Sedangkan penyuluhan terkait dengan sikap (Mathis dan Jackson, 2006:17) dalam bentuk: (1) ketertarikan dan (2) kesadaran akan pentingnya berkoperasi.

Permasalahan studi ini dapat dirumuskan sebagai berikut: (1) Apakah pendidikan berpengaruh terhadap partisipasi anggota?; (2) Apakah pelatihan berpengaruh terhadap partisipasi anggota?; (3) Apakah penyuluhan berpengaruh terhadap partisipasi anggota? dan (4) Apakah pendidikan, pelatihan dan penyuluhan berpengaruh secara simultan terhadap partipasi anggota Koppontren?.

\section{Partisipasi Anggota}

Mutis (1992:31) menjelaskan bahwa, produktivitas koperasi secara luas ditunjukkan oleh mutu partisipasi anggota. Hendar dan Kusnadi (2002:12) mendeskripsikan, partisipasi merupakan faktor yang paling penting dalam mendukung keberhasilan atau perkembangan suatu organisasi koperasi. Sedangkan Hicks, et al (2007:4-16), anggota koperasi mendapat keuntungan dalam kaitannya dengan patisipasi ekonomi dan sosial mereka dalam koperasi.

Tojjib (2005:30) menyatakan, secara umum partisipasi didefiniskan sebagai kerjasama antara rakyat dan pemerintah dalam merencanakan, melaksanakan, melestarikan dan mengembangkan hasil pembangunan. Syufri (2005:29) menjelaskan, partisipasi adalah bila dia terlibat secara aktif pada proses pengambilan keputusan dalam perencanaan, pelaksanaan dan pemantauan suatu kegiatan program tertentu. Sedangkan Dewanto (2005:8) mendeskripsikan, partisipasi adalah pelibatan diri pada suatu tekad yang telah menjadi kesepakatan bersama.

Deputi Bidang Pengembangan SDM Kementerian Koperasi dan Usaha Kecil dan Menengah (2010:2), partisipasi anggota juga dapat diartikan sebagai keikutsertaan anggota dalam berbagai 
bentuk kegiatan yang diselenggarakan oleh koperasi, baik kedudukan anggota sebagai pemilik maupun sebagai pengguna/pelanggan. Keikutsertaan anggotaini diwujudkan dalam bentuk pencurahan pendapat dan pikiran dalam pengambilan keputusan, dalam pengawasan, kehadiran dan keaktifan dalam rapat anggota, pemberian kontirbusi modal keuangan, serta pemanfaatan pelayanan yang diberikan oleh koperasi. Secara umum, partisipasi anggota koperasi menyangkut partisipasi terhadap sumberdaya, pengambilan keputusan, dan pemanfaatan, atau seringkali dibuat kategori partisipasi kontributif, partisipasi insentif.

Sedangkan Siswoyo (2004:28) dalam studinya menjelaskan, untuk mengukur tingkat partisipasi anggota koperasi menggunakan indikator: (1) partisipasi kontribusi pemilik; (2) partisipasi kontribusi pengambil keputusan dan (3) partisipasi kontribusi insentif. Berdasar pendapatan di atas, sebenarnya keberadaan anggota dalam badan usaha koperasi tidak saja sebagai pelanggan dan pemilik. Tetapi lebih dari itu, yaitu mampu mengimplementasikan bahwa koperasi berasal dari anggota, oleh anggota dan untuk anggota seperti yang dikemukakan oleh Nirbito (2001:15), bahwa anggota koperasi berposisi sebagai "pengguna-pemilik', "pengguna-pengendali" dan "pengguna-penikmat". Zeuli dan Cropp (1980:2) mendefinisikan bahwa, koperasi adalah pengguna-pemilik, pengguna-pengendali dan pendistribusian SHU secara proporsional.

Sedangkan dalam konteks internasional, menurut rumusan prinsip koperasi yang ke-dua International Co-operative Alliance (ICA) tahun 1995 menyatakan bahwa, pengendalian oleh anggota secara demokratis. Ini berarti bahwa anggota juga menjalankan fungsi pengendalian.

Nirbito (2001:19) dalam penelitiannya yang bertujuan untuk mengkaji secara empiris tentang seberapa jauh kualitas program pembinaan anggota yang telah dilaksanakan pengurus selama ini menurut kacamata persepsi anggota koperasi memang secara signifikan berdampak positif terhadap: (1) kualitas individu anggota; (2) kualitas kinerja organisasi; (3) kualitas kinerja usaha dan (4) kualitas keberhasilan pencapaian tujuan koperasi di lingkungan koperasi primer pedagang pasar (KOPPAS) dan koperasi wanita 
(KOPWAN) di Jawa Timur. Variabel-variabel mediator dalam penelitian ini adalah: (1) kualitas individu anggota; (2) kinerja organisasi dan (3) kinerja usaha.

Dengan metode survey korelasional serta analisis regresi linear multiple stepwise dan pengujian efek mediasinya menggunakan statistik uji Sobel Test, secara komposit kualitas program pembinaan anggota selama ini memang memberikan sumbangan positif signifikan (10,3\%) terhadap kualitas keberhasilan pencapaian tujuan koperasi. Namun dilihat secara parsial, sumbangan tersebut masih lebih rendah kadarnya dibandingkan dengan sumbangan yang berasal dari variabel mediatornya.

Dalam penelitian ini partisipasi anggota koperasi memperluas temuan Nirbito (2001:56). Yaitu bahwa pemenuhan kewajiban dan penggunaan hak dari anggota koperasi diarahkan pada posisi anggota sebagai "pengguna-pemilik', "pengguna-pengendali" dan "pengguna-penikmat". Teori yang sama dikemukakan oleh Dunn dalam Gray \& Butler (1991:38) serta Zeuli dan Cropp (1980:44) bahwa koperasi mengorangkan anggota dalam arti anggota dituntut untuk tidak pasif melainkan aktif. Sehingga bentuk partisipasi anggota dalam penelitian ini merujuk pada temuan dan teori di atas, serta merujuk pada ICA (1995) bahwa partisipasi anggota koperasi didasarkan pada posisi anggota sebagai: pemilik, pengendali dan pengguna.

Berdasar pemikiran di atas, indikator partisipasi anggota dalam penelitian ini yaitu: (1) partisipasi anggota sebagai pemilik (owner) yang dideskripsikan dalam bentuk ketepatan membayar simpanan wajib, pertambahan simpanan sukarela dan kehadiran dalam Rapat Anggota; (2) partisipasi anggota sebagai pengendali (controller) yang dideskripsikan dalam bentuk keaktifan memberikan kritik untuk perkembangan koperasi, keaktifan memberikan saran untuk perkembangan koperasi dan keaktifan mengambil tindakan untuk menghindari kerugian koperasi serta (3) partisipasi anggota sebagai pengguna (user) yang dideskripsikan dalam bentuk transaksi dengan koperasi, jumlah transaksi (banyaknya rupiah maupun volumenya) dan pembagian sisa hasil usaha (SHU) secara proporsional. 


\section{Pembinaan Anggota dalam Bentuk Pendidikan, Pelatihan dan Penyuluhan}

Pendidikan, pelatihan dan penyuluhan merupakan bentuk implementasi dari pembinaan anggota koperasi yang secara empiris menjadi sarana untuk meningkatkan peran serta aktif anggota. Pengembangan sistem pendidikan, peltihan dan penyuluhan perkoperasian bagi anggota dan pengelola koperasi, calon anggota dan kader koperasi, terutama untuk menanamkan nilai-nilai dasar dan prinsip-prinsip koperasi dalam kehidupan koperasi, yang mengatur secara jelas adanya pembagian tugas dan tanggung jawab antara pemerintah dan gerakan koperasi.

Setiawan (2005:34) dalam studinya menjelaskan, bahwa pembinaan dalam bentuk pendidikan, pelatihan, penyuluhan dan pemeliharaan organisasi yaitu usaha menjaga eksistensi organisasi dapat meningkatkan partisipasi anggota. Galor (1997:24-26) mendeskripsikan, bahwa kesuksesan sebuah koperasi tergantung pada besarnya tingkat seberapa baik anggota-anggotanya memahami prinsip-prinsip koperasi melalui pendidikan yang mereka enyam.

Mengingat pendidikan, pelatihan dan penyuluhan merupakan salah satu implementasi dari pembinaan anggota tentang perkoperasian, maka pembinaan anggota (dalam hal ini pendidikan anggota) berhubungan dengan kemampuan anggota dalam memahami prinsip-prinsip koperasi khususnya prinsip ketiga yaitu pembagian sisa hasil usaha dilakukan secara adil sebanding dengan besarnya jasa usaha masing-masing anggota. Aryhan, et al (2007:27) menjelaskan, pembinaan (pendidikan) berhubungan nyata dengan partisipasi petani padi sawah dalam kegiatan kelompok P3A.

Teori yang dikemukakan oleh Syarif (2002:22), bahwa otonomisasi koperasi secara harfiah dapat diartikan sebagai upaya untuk menjadikan koperasi sebagai badan usaha ekonomi independen yang dapat mengambil keputusan sendiri dan dalam berusaha tidak bertentangan dengan norma atau kaidah hukum yang berlaku. Keberhasilan otonomisasi ini dibangun atas dasar dua aspek yaitu aspek eksternal dan internal. Dari aspek eksternal beberapa peubah yang diduga secara langsung mempengaruhi keberhasilan otonomisasi koperasi adalah pembinaan pemerintah (dalam bentuk 
pendidikan koperasi). Berdasar aspek internal beberapa peubah yang diduga berpengaruh terhadap otonomi koperasi, antara lain partisipasi anggota.

Jacub (1986:27) dalam penelitiannya yang bertujuan untuk menelusuri dampak dari pendidikan dan latihan atau penyuluhan perkoperasian di kalangan warga koperasi yang telah tumbuh di lingkungan Pontren di Indonesia, terutama di Jawa Barat. Fokus studi ini relevan dengan suatu cita-cita meningkatkan peranan koperasi dalam perekonomian nasional, meliputi pembinaan sumber daya manusia yang telah menjadi warga koperasi atau belum. Jika gerakan koperasi di Indonesia sukses, maka pada gilirannya akan meningkatkan taraf hidup warganya dan membatasi kemiskinan.

Unit analisis dari studi penelitian ini adalah para anggota biasa dan anggota pengurus Koppontren. Sebagai sampel dalam penelitian ini bukan hanya para santri dan para pengasuh Pontren saja, tetapi juga warga masyarakat di luar Pontren yang menjadi warga koperasi itu. Metodologi yang digunakan adalah pendekatan interdisiplin dan teknik-teknik yang biasa digunakan dalam deskriptif analitik. Data dari hasil penelitian mengenai program latihan dan penyuluhan koperasi di Koppontren itu diolah dengan menggunakan pendekatan kuantitatif dan kualitatif.

Hasil penelitian menunjukkan bahwa perencanaan pendidikan luar sekolah perkoperasian yang dikembangkan menurut kebutuhan terbatas atau lokal dan diasuh oleh sumber belajar yang memahami seluk beluk pondok pesantren atau pernah menjadi orang pesantren, tampaknya lebih besar kemanfaatannya. Sebagian besar baru dalam pengadaan kapital misalnya ada lembaga yang dapat memberi pinjaman modal tanpa bunga dan menggunakan sistem bagi hasil ( $m u$ dhorobah), untuk masa mendatang. Penelitian lebih lanjut mengenai aspek-aspek kelemahan manajemen, kesenjangan dalam menerapkan organisasi modern perlu dikembangkan dalam upaya remidial untuk kemajuan Koppontren selanjutnya.

Penelitian Samsuri (2005:31) pada Koperasi Perternakan Bandung Selatan (KPBS) yang menggunakan metode penelitian studi kasus dengan analisis kualitatif yang dipadukan dengan analisis kuantitatif dengan mengambil sampel sebanyak 276 orang anggota 
yang tersebar di Kecamatan Pangalengan dan Kertasari. Responden tambahan: Pengurus, Badan Pemeriksa KPBS dan Pembina KPBS. Instrumen yang digunakan untuk memperoleh data primer: kuesioner, tes skala sikap dan tes kepemimpinan. Data sekunder diambil dari laporan tahunan KPBS dan laporan-laporan penelitian atau publikasi lainnya.

Adapun hasil analisis data dan pengujian hipotesis serta kesimpulan penelitian ini adalah: (1) partisipasi anggota dalam koperasi bila dirata-ratakan, sebagian besar masuk katagori tinggi; (2) secara kuantitatif hipotesis diterima bahwa terdapat korelasi antara variabel persepsi, pendidikan formal, mentalitas dan pemilikan dengan parrtisipasi anggota dalam koperasi; (3) dengan teknik elaborasi diketahui bahwa setelah dikontrol dengan variabel bebas dengan variabel terikat secara statistik tidak berubah; (4) yang cukup menarik dari hasil itu bahwa variabel pendidikan formal berkorelasi secara negatif dengan partisipasi. Hal tersebut diperkirakan karena faktor sistem pendidikan dan skala usaha koperasi tersebut; (5) partisipasi anggota dalam koperasi dan perkembangan koperasi terbukti dapat meningkatkan kesejahteraan anggota; (6) hal-hal yang mendukung perkembangan KPBS dan yang merupakan daya hidupnya adalah daya internal (anggota, pengurus dan skala usaha) dan daya eksternal (pemerintah, lingkungan alam dan latar belakang sejarah) dan (7) dalam rangka menuju kepada koperasi yang mandiri, disarankan agar baik warga KPBS maupun pemerintah mengadakan usaha-usaha yang mendorong ke arah terwujudnya cita-cita tersebut.

Pengaruh positif variabel pendidikan, pelatihan dan penyuluhan sebagaimana yang ditemukan Nirbito, Jacub dan Samsuri relevan dengan penelitian Setiawan, Galor, Aryhan dan Kambuaya. Setiawan (2005:25) dalam studinya menjelaskan, bahwa pembinaan dan pemeliharaan organisasi yaitu usaha menjaga eksistensi organisasi dapat meningkatkan partisipasi anggota. Galor (1997:2426) medeskripsikan, bahwa kesuksesan sebuah koperasi tergantung pada besarnya tingkat seberapa baik anggota-anggotanya memahami prinsip-prinsip koperasi melalui pendidikan yang mereka enyam. Aryhan, et al (2007:18) menjelaskan, pembinaan berhubungan nyata dengan partisipasi petani padi sawah dalam kegiatan 
kelompok P3A, sedangkan Kambuaya (1993:45) dalam penelitiannya menjelaskan, pembinaan yang dilakukan terhadap koperasi meliputi berbagai aspek, antara lain pembinaan kelembangaan koperasi untuk meningkatkan partisipasi para anggota.

Landasan hukum terkait pentingnya pendidikan ini sebagaimana firman Allah SWT antara lain: (1) Dan Dia mengajarkan kepada Adam nama-nama (benda-benda) seluruhnya, kemudian mengemukakannya kepada para Malaikat lalu berfirman: "Sebutkanlah kepada-Ku nama benda-benda itu jika kamu mamang benar orang-orang yang benar!" (QS. 2:31); (2) Dan rendahkanlah dirimu terhadap mereka berdua dengan penuh kesayangan dan ucapkanlah: "Wahai Tuhanku, kasihilah mereka keduanya, sebagaimana mereka berdua telah mendidik aku waktu kecil" (QS. 17:24) dan (3) Mereka menanyakan kepadamu: "Apakah yang dihalalkan bagi mereka?" Katakanlah: "Dihalalkan bagimu yang baik-baik dan (buruan yang ditangkap) oleh binatang buas yang telah kamu ajar dengan melatihnya untuk berburu; kamu mengajarnya menurut apa yang telah diajarkan Allah kepadamu. Maka makanlah dari apa yang ditangkapnya untukmu, dan sebutlah nama Allah atas binatang buas itu (waktu melepaskannya). Dan bertakwalah kepada Allah, sesungguhnya Allah amat cepat hisab-Nya (QS. 5:4).

Kemudian Pembukaan Undang-Undang Dasar 1945 menyatakan "mencerdaskan kehidupan bangsa" yang berarti pendiri bangsa sejak awal telah merekomendasikan kepada Pemerintah Negara Indonesia untuk mencerdasarkan kehidupan bangsa. Selanjutnya dideskripsikan bahwa, setiap warga negara berhak mendapat pendidikan (Pasal 31 ayat 1 UUD 1945 perubahan IV 10 Agustus 2002). Dalam kaitannya dengan koperasi dinyatakan bahwa, dalam mengembangkan koperasi, maka koperasi melaksanakan pula prinsip koperasi antara lain pendidikan perkoperasian (UU No 25/ 1992 pasal 5 ayat 2 a).

Berdasar pemikiran di atas, pendidikan dalam penelitian ini diarahkan pada pendidikan perkoperasian yang dilaksanakan baik oleh lembaga eksternal maupun internal Koppontren untuk membangun tingkat pengetahuan (knowledge), tingkat pemahaman (comprehension) dan tngkat penerapan (application) para anggotanya. Pelatihan diarahkan pada pelatihan perkoperasian 
anggota yang dilaksanakan baik oleh lembaga eksternal maupun internal Koppontren dengan cara: (1) menawarkan model untuk merebut perhatian yang dilatih; (2) memberikan sifat-sifat motivasional; (3) membantu yang dilatih agar membekas apa yang telah dipelajari untuk digunakan kelak dan (4) memberikan kesempatan untuk mempraktikkan perilaku baru. Sedangkan penyuluhan diarahkan pada penyuluhan perkoperasian anggota yang diarahkan pada ketertarikan anggota terhadap Koppontren dan kesadaran akan pentingnya berkoperasi.

\section{Metode Penelitian}

Menurut pendekatannya, penelitian ini termasuk dalam penelitian kuantitatif dengan desain penelitian model cross-sectional. Teknik penarikan sampel menggunakan acak bertingkat (Multistage Random Sampling) sehingga diperoleh sampel sebanyak 320 orang yang selanjutnya merupakan responden penelitian. Sedangkan untuk memilih Pontren sampel dan responden penelitian berasal dari populasi yaitu seluruh Pontren yang ada di Kabupaten Tulungagung, diambil 35 Pontren yang memiliki Koppontren sebagai sampel. Proses pemilihan sampel dilakukan dengan menstratifikasi berdasar dua kategori: (1) Pontren yang memilki Koppontren yang sudah berbadan hukum dan (2) Pontren yang memiliki Koppontren yang belum berbadan hukum.

Berdasarkan dua pertimbangan tersebut, kemudian diambil secara proporsional anggota Koppontren untuk dijadikan sebagai responden yang nantinya bisa mewakili keragaman Koppontren yang ada di Kabupaten Tulungagung. Sedangkan untuk memilih responden anggota Koppontren dilakukan secara acak (random). Variabel penelitian terdiri dari variabel dependen (terikat) yaitu partisipasi anggota (Y) dan variabel independen (bebas) yaitu pendidikan $\left(\mathrm{X}_{1}\right)$, pelatihan $\left(\mathrm{X}_{2}\right)$ dan penyuluhan $\left(\mathrm{X}_{3}\right)$.

Data penelitian dikumpulkan menggunakan angket dalam bentuk skala sikap dari Likert, berupa pernyataan tentang variabel penelitian dan menggunakan lima alternatif jawaban, yaitu: sangat setuju (ST), sangat sering (SR), selalu (SL); setuju (SJ), sering (SG), kadang-kadang (KD); netral (NL); tidak setuju (TS), jarang (JR); 
dan sangat tidak setuju (STS), tidak pernah (TP). Skor untuk jawaban dari pernyataan adalah $\mathrm{ST}=\mathrm{SR}=\mathrm{SL}=5, \mathrm{SJ}=\mathrm{SG}=\mathrm{KD}=4, \mathrm{NL}=3$, $\mathrm{TS}=\mathrm{JR}=\mathrm{STS}=\mathrm{TP}=1$.

Uji coba (try out) terhadap instrumen penelitian dilakukan kepada subjek coba sebanyak 30 orang yang selanjutnya dilakukan uji validitas dan reliabilitas instrumen. Hasil uji ini menunjukkan bahwa variabel pendidikan (nomor item $1 \mathrm{~s} / \mathrm{d}$ 9), pelatihan (nomor item $10 \mathrm{~s} / \mathrm{d}$ 17) dan penyuluhan (nomor item $18 \mathrm{~s} / \mathrm{d} 22$ ) valid dengan tingkat signifikansi 0,01. Sedangkan variabel partisipasi anggota dengan nomor item 1 s/d 20 juga valid dengan tingkat signifikansi 0,01 . Uji reliabilitas instrumen menunjukkan bahwa nilai koefisien variabel pendidikan $(0,768)$, pelatihan $(0,762)$, penyuluhan $(0,770)$ dan partisipasi anggota $(0,768)$ lebih besar dibanding Cronbach's Alpha $(0,6)$. Hasil ini berarti bahwa seluruh butir pernyataan adalah reliabel/konsisten dan bila digunakan beberapa kali untuk mengukur objek yang sama, akan menghasilkan data yang sama pula.

Analisis data penelitian menggunakan regresi linear berganda, dan karena model ini termasuk dalam statistika parametrik maka sebelumnya dilakukan uji normalitas data dan pengujian asumsi klasik (multikolinearitas dan heteroskedastisitas) menggunakan software SPSS versi 19.

\section{Uji Instrumen dan Ketepatan Model}

Berdasar uji validitas, instrumen variabel pendidikan $\left(\mathrm{X}_{1}\right)$ yang terdiri dari 9 item, variabel pelatihan $\left(\mathrm{X}_{2}\right)$ yang terdiri dari 8 item, variabel penyuluhan $\left(\mathrm{X}_{3}\right)$ yang terdiri dari 5 item dan variabel partisipasi anggota (Y) yang terdiri dari 20 item menunjukkan bahwa seluruh item valid karena nilai corrected item-total correlation lebih besar dibanding 0,3 seperti yang dijelaskan oleh Sugiyono (2004:35) yang menyatakan bila korelasi tiap faktor positif dan besarnya 0,3 ke atas maka faktor tersebut merupakan construct yang kuat. Sedangkan hasil uji reliabilitas pada keempat variabel penelitian didasarkan pada nilai Cronbach's Alpha sebagai berikut: variabel pendidikan $\left(\mathrm{X}_{1}\right)$ sebesar 0,917 , variabel pelatihan $\left(\mathrm{X}_{2}\right)$ sebesar 0,891 , variabel penyuluhan $\left(\mathrm{X}_{3}\right)$ sebesar 0,785 dan variabel partisipasi 
anggota (Y) sebesar 0,913 yang berarti bahwa konstruk dimensi variabel-variabel penelitian adalah reliabel. Karena angka Cronbach's Alpha seluruh variabel lebih besar dari 0,60 seperti yang dikemukakan oleh Nugroho (2005:42).

Pengujian normalitas data dilakukan secara univariate dan multivariate. Secara univariate terhadap variabel-variabel penelitian memberikan hasil yang tidak signifikan ( $\mathrm{p}$-value $>0,05$ ) baik pada nilai skewness, kurtosis. Pemeriksaan asumsi distribusi normal univariate dilakukan terhadap tingkat signifkansi hasil uji skewness dan kurtosis. Data berdistribusi normal secara univariate jika hasil uji adalah tidak signifikan. Berikut ini adalah hasil uji p-value baik untuk skewness maupun kurtosis masing-masing variabel: pendidikan $(0,949 ; 0,831)$, pelatihan $(0,978 ; 0,986)$, penyuluhan $(0,918 ; 0,906)$ dan partisipasi anggota $(0,897 ; 0,867)$.

Selanjutnya agar model persamaan regresi berganda berbasis ordinary least square (OLS) terpenuhi, maka harus memenuhi syarat antara lain multikolinearitas dan heteroskedastisitas. Standar pengujian multikolinearitas dilakukan dengan melihat nilai Variance Inflation Factor (VIF). Berdasar hasil olah data (coefficients) diketahui bahwa nilai VIF adalah: 1,854 (variabel pendidikan); 1,813 (variabel pelatihan) dan 1,208 (variabel penyuluhan) yang berarti variabel terbebas dari asumsi klasik multikolineaitas, karena hasilnya lebih kecil dari 10. Standar pengujian heteroskedastisitas dalam studi ini menggunakan metode Glejser test, yaitu dengan cara meregresikan nilai absolute residual terhadap variabel pendidikan, pelatihan dan penyuluhan. Berdasar hasil perhitungan menunjukkan tidak ada gangguan heteroskedastisitas, dimana tidak ada nilai $\mathrm{t}_{\text {hitung }}$ yang signifikan atau nilai signifikan (sig) lebih besar dari $\alpha=0,05$ $(\mathrm{p}>0,05)$. Nilai $\mathrm{t}_{\text {sig }}$ variabel pendidikan sebesar 0,354 , variabel pelatihan sebesar 0,555 dan variabel penyuluhan sebesar 0,254.

Setelah dilakukan pengujian-pengujian yaitu: (1) validitas dan reliabilitas instrumen; (2) uji normalitas data dan (3) ujian asumsi klasik, langkah berikutnya melakukan uji regresi berganda. Berdasar perhitungan, persamaan regresi berganda penelitian ini yaitu:

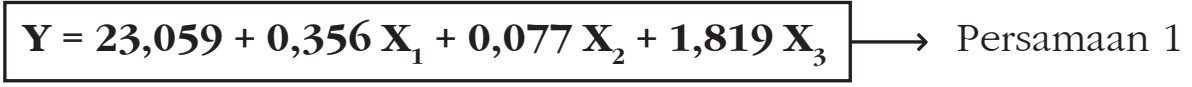


Dari persamaan regresi berganda di atas dapat diartikan pengaruh masing-masing variabel bebas (X) sebagai berikut: (1) satu poin kenaikan nilai variabel pendidikan $\left(\mathrm{X}_{1}\right)$ menyebabkan kenaikan nilai variabel partisipasi anggota (Y) sebesar 0,356 ditambah konstanta sebesar 23,059; (2) satu poin kenaikan nilai variabel pelatihan $\left(\mathrm{X}_{2}\right)$ menyebabkan kenaikan nilai variabel partisipasi anggota (Y) sebesar 0,077 ditambah konstanta sebesar 23,059 dan (3) satu poin kenaikan nilai variabel penyuluhan $\left(\mathrm{X}_{3}\right)$ menyebabkan kenaikan nilai variabel partisipasi anggota $(\mathrm{Y})$ sebesar 1,819 ditambah konstanta sebesar 23,059.

Pengujian hipotesis yang diajukan dalam penelitian ini melalui uji parsial (uji t) dan uji serentak (uji F). Uji t dilakukan untuk menguji hipotesis sebagai berikut: hipotesis pertama, pendidikan berpengaruh signifikan terhadap partisipasi anggota. Untuk menguji hipotesis pertama, kedua dan ketiga dengan membandingkan nilai $\mathrm{t}_{\text {sig }}$ dengan á=0,05 dengan pedoman jika $\mathrm{t}_{\text {sig }}<\alpha=0,05$ maka hipotesis alternatif diterima dan menolak hipotesis null. Berdasar pengujian data, nilai $t_{\text {sig }}$ variabel pendidikan sebesar $0,001<\alpha=0,05$ yang berarti hipotesis pertama teruji bahwa pendidikan berpengaruh signifikan terhadap partisipasi anggota. Hipotesis kedua, pelatihan berpengaruh signifikan terhadap partisipasi anggota. Berdasar pengujian data, nilai $t_{\text {sig }}$ variabel pelatihan sebesar $0,555>\alpha=0,05$ yang berarti hipotesis kedua tidak teruji bahwa pelatihan tidak berpengaruh signifikan terhadap partisipasi anggota. Hipotesis ketiga, penyuluhan berpengaruh signifikan terhadap partisipasi anggota. Berdasar pengujian data, nilai $t_{\text {sig }}$ variabel penyuluhan sebesar 0,000 $<\alpha=0,05$ yang berarti hipotesis ketiga teruji bahwa penyuluhan berpengaruh signifikan terhadap partisipasi anggota. Sedangkan hipotesis keempat, pendidikan, pelatihan dan penyuluhan secara simultan berpengaruh signifikan terhadap partipasi anggota Koppontren diuji dengan uji $\mathrm{F}$ yang membandingkan nilai $\mathrm{F}_{\text {sig }}$ dengan $\alpha=0,05$. Pedomannya, jika $\mathrm{F}_{\text {sig }}<\alpha$ maka hipotesis alternatif diterima dan menolak hipotesis null dan sebaliknya. Berdasar hasil analisis data diketahui bahwa nilai $\mathrm{F}_{\text {sig }}$ sebesar $0,000<\alpha=0,05$ yang berarti hipotesis keempat teruji. 


\section{Analisis}

Berdasar hasil penelitian (perhatikan persamaan 1), menunjukkan bahwa koefisien regresi dari konstruk pendidikan ke konstruk partisipasi anggota bernilai 0,356 dengan $\mathrm{t}_{\text {sig }}$ sebesar 0,000 (lebih kecil dari $\alpha=0,05)$. Melalui pendidikan tentang perkoperasian, diharapkan anggota memiliki 3 kompetensi yaitu: pengetahuan (knowledge), pemahaman (comprehension) serta mampu menerapkan (application) AD dan ART Koppontren. Pendidikan anggota merupakan landasan utama yang dibutuhkan untuk munculnya rasa memiliki anggota terhadap Koppontren. Sebagaimana yang tercermin dalam prinsip-prinsip koperasi, bahwa bukannya koperasi yang memiliki anggota, tetapi anggotalah yang memiliki koperasi. Koperasi merupakan organisasi yang ekonomi sekaligus sosial. Keduanya bagaikan dua sisi mata uang yang tidak bisa dipisahkan. Satu kata yang mempertemukan kedua sisi ini adalah pendidikan. Koppontren tidak dapat berkembang tanpa adanya pendidikan.

Studi Nasution (2007:7) menyatakan bahwa, pendidikan anggota merupakan pendidikan untuk menanamkan karakter positif seperti sifat tekun, pantang menyerah, aktif melakukan inovasi, solider terhadap sesama, serta karakter lain yang diperlukan untuk kemajuan, sekaligus pendidikan untuk mengasah wawasan dan keahlian anggota dalam mengelola koperasinya. Sedangkan Prakash (2008:46) mendeskripsikan bahwa, program-program pendidikan anggota diselenggarakan untuk memudahkan proses partisipasi anggota. Birchall dan Simmons (2004:30) mengemukakan bahwa, untuk meraih kesuksesan dalam berkoperasi, para anggota harus memiliki sumber daya cukup untuk mampu mengambil bagian secara efektif. Sumber daya tersebut antara lain pendidikan.

Berdasar hasil penelitian, indikator pendidikan ini dideskripsikan menjadi 3 deskriptor yaitu: tingkat pengetahuan (knowledge); tingkat pemahaman (comprehension) dan tingkat penerapan (application). Pertama deskriptor tingkat pengetahuan, yang dijabarkan menjadi 3 item. Untuk item wawasan mengenai Anggaran Dasar Koppontren, anggota mempersepsikan bahwa Koppontren sering memberikan pendidikan untuk membangun wawasan mengenai Anggaran Dasar Koppontren kepada anggota. Item wawasan menge- 
nai Anggaran Rumah Tangga Koppontren, anggota mempersepsikan bahwa Koppontren sering memberikan pendidikan untuk membangun wawasan mengenai Anggaran Rumah Tangga Koppontren kepada anggota. Sedangkan item wawasan mengenai perkembangan Koppontren menurut ketentuan Anggaran Dasar, mayoritas anggota bersikap netral terhadap item pernyataan ini.

Hasil ini berarti, ditinjau dari aspek frekuensi, sebenarnya Koppontren sering melakukan pendidikan untuk membangun wawasan mengenai Anggaran Dasar dan Anggaran Rumah Tangga Koppontren kepada anggota. Tetapi karena pendidikan yang diberikan tidak dilaksanakan secara serius dan terkesan hanya untuk memenuhi persyaratan saja maka hasilnya tidak bisa memberikan kontribusi terhadap kualitas partisipasi anggota. Implikasinya, anggota tidak memiliki wawasan yang utuh mengenai perkembangan Koppontren menurut ketentuan Anggaran Dasar yang dibuktikan dengan mayoritas anggota bersikap netral terhadap item pernyataan ini.

Kedua, deskriptor tingkat pemahaman, yang dijabarkan menjadi 3 item. Untuk item dapat menjelaskan kembali mengenai Anggaran Dasar dan Anggaran Rumah Tangga Koppontren, mayoritas responden jarang dan netral dapat menjelaskan kembali mengenai Anggaran Dasar dan Anggaran Rumah Tangga Koppontren. Sedangkan item dapat menjelaskan kembali mengenai perkembangan Koppontren menurut ketentuan Anggaran Dasar, mayoritas anggota bersikap netral terhadap item pernyataan ini.

Berdasar deskriptor ini, kualitas program pembinaan yang diselenggarakan baik oleh internal maupun eksternal Koppontren belum mampu memberikan pemahaman mengenai Anggaran Dasar dan Anggaran Rumah Tangga kepada anggota. Sehingga anggota secara umum belum mengetahui kewajibannya sebagai anggota Koppontren, oleh karenanya wajar jika tidak bepengaruh signifikan terhadap partisipasi anggota.

Ketiga, deskriptor tingkat penerapan, yang dijabarkan menjadi 3 item. Untuk item dapat menerapkan Anggaran Dasar dan Anggaran Rumah Tangga Koppontren, mayoritas responden menjawab sering dan netral dapat menjelaskan kembali mengenai Anggaran Dasar Koppontren. Sedangkan item dapat memecahkan berbagai masalah 
terkait dengan perkembangan Koppontren menurut ketentuan Anggaran Dasar, mayoritas anggota bersikap netral terhadap item pernyataan ini.

Berdasar deskriptor ini, kualitas program pembinaan yang diselenggarakan baik oleh internal maupun eksternal Koppontren belum secara total dipahami oleh anggota. Hal ini dibuktikan dengan lemahnya kemampuan anggota dalam menjelaskan kembali dan memecahkan berbagai masalah Koppontren. Karena anggota belum mampu menjelaskan kembali mengenai Anggaran Dasar dan Rumah Tangga Koppontren, sehingga anggota juga belum mampu dalam memecahkan berbagai masalah Koppontren. Masalah Koppontren dalam hal ini adalah kualitas partisipasi anggota. Jadi dalam studi ini menemukan bahwa, pendidikan anggota belum secara total mampu memperbaiki kualitas partisipasi anggota Koppontren yang disebabkan oleh dua hal yaitu: aspek frekuensi dan aspek kualitas program pendidikan.

Demikian halnya dengan pelatihan. Melalui pelatihan tentang perkoperasian, diharapkan anggota memiliki: motivasi untuk berkoperasi serta terampil dalam berbisnis secara praktis. Archimède (2007:41) menjelaskan bahwa, pelatihan adalah satu bagian penting dari suatu aktivitas perusahaan. Pada Koppontren, pelatihan pada para anggota secara terus menerus merupakan aktivitas untuk menanamkan pengetahuan anggota terhadap Koppontren untuk siap dalam menghadapi tantangan-tantangan baru yang dengan cepat mengubah dunia. Karena itu suatu pelatihan yang spesifik untuk para anggota harus secara teratur disediakan. Namun beberapa Koppontren tidak mempunyai pelatihan secara spesifik, sedangkan yang lainnya mengalami kesulitan untuk menetapkan suatu program yang riil dari aktivitas pelatihan atau pelatihan tidak diberi perhatian secara serius. Kalau ini yang terjadi, maka para anggota kekurangan pengetahuan tentang isu-isu yang bersifat Koppontren seperti permasalahan bisnis.

Jadi, Koppontren perlu menetapkan kursus pelatihan kepada para anggota. Bahkan jenis pelatihan yang disediakan mestinya tidak hanya terkait dengan permasalahan bisnis. Tetapi juga harus mencakup aspek yang dihubungkan dengan pengembangan kepekaan dan pengetahuan tentang perkoperasian. Birchall dan 
Simmons (2004:30) mengemukakan bahwa, untuk meraih kesuksesan dalam berkoperasi, para anggota harus memiliki sumber daya cukup untuk mampu mengambil bagian secara efektif. Sumber daya tersebut antara lain pelatihan.

Berdasar hasil penelitian, indikator pelatihan ini dideskripsikan menjadi 4 deskriptor yaitu: (1) menawarkan model untuk merebut perhatian yang dilatih; (2) memberikan sifat-sifat motivasional; (3) membantu yang dilatih agar membekas apa yang telah dipelajari untuk digunakan kelak dan (4) memberikan kesempatan untuk mempraktikkan perilaku baru. Deskriptor yang pertama dijabarkan menjadi 2 item. Untuk item Koppontren sering memberikan pelatihan dalam bentuk keterampilan praktis dan item Koppontren sering memberikan pelatihan keterampilan yang memanfaatkan potensi daerah, mayoritas responden menjawab jarang. Hasil ini mempengaruhi kualitas partisipasi anggota Koppontren, karena program pelatihan belum menyentuh pada kebutuhan substansial anggota Koppontren di Kabupaten Tulungagung. Ciri masyarakat Tulungagung pada umumnya adalah berwirausaha, misalnya dibidang konveksi. Seharusnya, pelatihan kepada anggota diarahkan pada bentuk-bentuk pelatihan praktis yang memanfaatkan potensi daerah.

Deskriptor yang kedua dideskripsikan oleh 2 item pernyataan, dimana anggota merasa bahwa program pelatihan sering mengedepankan peran serta aktif anggota dan sering melibatkan semua anggota dalam program pelatihan. Deskriptor yang ketiga dideskripsikan oleh 2 item pernyataan, yang terkait dengan pemateri (netral) dan manfaat pelatihan bagi anggota (sering). Sedangkan deskriptor yang keempat dideskripsikan oleh 2 item pernyataan, dimana anggota Koppontren merasa sering diberi kesempatan untuk mempraktikkan keterampilan praktis secara memadai tetapi jarang terdapat kesempatan untuk mempraktikkan keterampilan praktis secara memadai serta memasarkan hasil praktik keterampilan praktis.

Jadi dalam studi ini menemukan bahwa, pelatihan anggota belum secara total mampu memperbaiki kualitas partisipasi anggota Koppontren yang disebabkan oleh dua hal yaitu: aspek frekuensi dan aspek kualitas program pelatihan. Walaupun program pelatihan sudah memberi ruang kepada anggota untuk mempraktikkan, tetapi 
kalau tidak responsif dengan potensi daerah setempat, hasil pelatihan juga tidak bisa maksimum yaitu belum mampu meningkatkan kualitas partisipasi anggota Koppontren.

Sedangkan penyuluhan terkait dengan sikap (Mathis dan Jackson, 2006:27) dalam bentuk: (1) ketertarikan dan (2) kesadaran akan pentingnya berkoperasi. Dengan penyuluhan diharapkan anggota memilki daya tarik untuk terus menjadi anggota Koppontren, sadar tentang arti pentingnya berkoperasi, memiliki rasa ikut memiliki dan bertanggungjawab terhaap kemandirian Koppontren. Deskriptor yang pertama dideskripsikan oleh 2 item pernyataan, dimana anggota setuju bahwa program penyuluhan perkoperasian dapat meningkatkan daya tarik dalam berkoperasi dan meningkatkan produktivitas usaha Koppontren. Deskriptor yang kedua dideskripsikan oleh 3 item pernyataan, dimana anggota setuju bahwa program penyuluhan perkoperasian dapat meningkatkan kesadaran dalam berkoperasi, menumbuhkan rasa ikut memiliki terhadap usaha Koppontren serta dapat menumbuhkan rasa ikut bertanggung jawab terhadap kemandirian Koppontren.

Jadi dalam studi ini menemukan bahwa, penyuluhan anggota belum secara total mampu memperbaiki kualitas partisipasi anggota Koppontren yang disebabkan oleh aspek implementasi. Yaitu, bahwa penyuluhan harus didukung oleh kemampuan dalam memahami Anggaran Dasar dan Rumah Tangga serta diarahkan pada bentuk-bentuk pelatihan praktis yang memanfaatkan potensi daerah. Anggota mengetahui bahwa penyuluhan dapat membangun ketertarikan dan kesadaran dalam berkoperasi. Tetapi penyuluhan ini merupakan salah satu dari paket pembinaan. Jika penyuluhan tidak didukung oleh pendidikan dan pelatihan, maka tetap saja sulit membangun kualitas partisipasi anggota dalam Koppontren.

\section{Kesimpulan}

Berdasar hasil penelitian, variabel pendidikan, pelatihan dan penyuluhan perkoperasian kepada anggota belum mampu mambangun partisipasi anggota Koppontren di Kabupaten Tulungagung. Kesimpulan ini disebabkan oleh tiga aspek yaitu: (1) program pembinaan anggota belum dilaksanakan secara terus menerus dan 
berkelanjutan; (2) kualitas program pembinaan yang belum mampu dalam: menanamkan informasi kognitif kepada anggota tentang hak dan kewajibannya sebagai anggota Koppontren, memberikan keterampilan maksimum kepada anggota, serta memaksimumkan sikap tertarik dan sadar akan pentingnya berkoperasi dan (3) aspek implemantasi. Yaitu program pembinaan anggota belum bisa dijalankan dengan memanfaatkan potensi daerah.

Oleh karenanya disarankan untuk menyusun kurikulum Pontren yang mengakomodasi terbentuknya wirausaha baru yang handal dan menjunjung tinggi etika melalui Koppontren. Kurikulum yang demikian ini diharapkan, Pontren tidak saja merupakan lembaga pendidikan agama tetapi juga lembaga pendidikan yang menyiapkan SDM unggul dan mandiri. Sehingga kinerja Koppontren dapat ditingkatkan ketika dekelola oleh SDM yang memiliki keunggulan dan kemandirian.

\section{Daftar Pustaka}

Amir, Saifuddin. 2006. Pesantren, Sejarah dan Perkembangannya. Bandung: Pustaka.

Archimède, Rue. 2007. Euro Coop Guidelines on Cooperative Governance. Communaute Europeenne Des Cooperatives De Consommateurs European Community Of Consumer CoOperatives. Brussels.

Aryhan, Josia Nurtanio; Tubagus Hasanudin, dan Dewangga Nikmatullah. 2007. Faktor-Faktor yang Berhubungan dengan Partisipasi Petani Padi Sawah dalam Kegiatan Kelompok P3A di Kecamatan Gading Rejo Kabupaten Tanggamus Provinsi Lampung. Penelitian Tidak Dipublikasikan. Jurusan Sosial Ekonomi Pertanian Universitas Lampung

Aryhan, Josia Nurtanio; Tubagus Hasanudin, dan Dewangga Nikmatullah. 2007. Faktor-Faktor yang Berhubungan dengan Partisipasi Petani Padi Sawah dalam Kegiatan Kelompok P3A di Kecamatan Gading Rejo Kabupaten Tanggamus Provinsi Lampung. Penelitian Tidak Dipublikasikan. Jurusan Sosial Ekonomi Pertanian Universitas Lampung 
Birchall, Johnston and Richard Simmons. 2004. What Motivates Members to Participate in the Governance of Consumer Cooperatives? A study of the Co-operative Group. Research carried out as part of the Stirling University Mutuality Research Programme, in partnership with the UK Co-operative College, and funded by the UK. Economic and Social Research Council.

Bloom, B.S. ed. et al. 1956. Taxonomy of Educational Objectives: Handbook 1, Cognitive Domain. New York: David McKay.

Dewanto, A. 2005. Menuju Arsitektur Berkelanjutan, (Online), (http://www.freelists.org/archives/ppi/09-2005/msg00029.html, diakses 24 Agustus 2007).

Direktorat Jenderal Koperasi. 1980. Tugas Pengurus dalam Mengelola Organisasi Koperasi.

Galor, Z. 1997. Criticising the Third ICA Principle. Co-op Dialogue, Vol.7, No.2, May-Aug. 1997.

Galor, Z. 1997. Criticising the Third ICA Principle. Co-op Dialogue, Vol.7, No.2, May-Aug. 1997.

Gray, T.W. \& Butler, G. 1991. Charting From Within a Grounded Concept of Member Control. Journal of Agricultural Cooperation, Vol. 6, pp. 82-93.

Hendar dan Kusnadi. 2002. Ekonomi Koperasi untuk Perguruan Tinggi. Edisi Revisi. Jakarta: Lembaga Penerbit FE UI.

Hicks, E.; Maddocks, J.: Robb, A.; Webb, T. 2007. Co-operative Accountability and Identity: An Examination of Reporting Practices of Nova Scotia Co-operatives. Journal of Cooperative Studies, 40(2).

Jacub, M. 1986. Partisipasi Anggota dan Hubungannya dengan Pendidikan Perkoperasian, Penampilan Pengurus, Serta Sistem Penghargaan: Suatu Studi Mengenai Karakteristik dan Masalah Pembinaan Koperasi di Lingkungan Pondok Pesantren. Disertasi tidak dipublikasikan. Bandung: Univ. Pendidikan Indonesia.

Jacub, M. 1986. Partisipasi Anggota dan Hubungannya dengan Pendidikan Perkoperasian, Penampilan Pengurus, Serta Sistem Penghargaan: Suatu Studi Mengenai Karakteristik 
dan Masalah Pembinaan Koperasi di Lingkungan Pondok Pesantren. Disertasi tidak dipublikasikan. Bandung: Univ. Pendidikan Indonesia.

Kambuaya. 1993. Potensi dan Prospek Pengembangan KUDGotong Royong Deasa Nimbokrang Kecamatan Nimboran. Penelitian. Jayapura: FE Univ.Cenderawasih.

Kambuaya. 1993. Potensi dan Prospek Pengembangan KUDGotong Royong Deasa Nimbokrang Kecamatan Nimboran. Penelitian. Jayapura: FE Univ.Cenderawasih.

Kementerian Koperasi dan Usaha Kecil Menengah. 2007. Revitaslisasi Koperasi dan UKM sebagai Solusi Mengatasi Pengangguran dan Kemiskinan. www.depkop.go.id/.../812-laporankinerja-kementerian-negara-koperasi-dan-ukm-tahun-2007ukuran-tabloida3-.html.

Mathis, Robert L dan Jackson, John H. 2006. Human Resource Management. Terjemahan. Diana Angelica. Jakarta: Salemba Empat.

Mutis, T. 1992. Pengembangan Koperasi: Kumpulan Karangan. Jakarta: PT Gramedia Widiasarana Indonesia.

Nasution, M. 24 Februari 2007. Prinsip Syariah dalam Koperasi. Republika.

Nirbito, J.G. 2001. Pembinaan Anggota untuk Memberdayakan Koperasi di Koppas dan Kopwan Jawa Timur. Disertasi tidak dipublikasikan. Malang: PPS UM.

Nirbito, J.G. 2001. Pembinaan Anggota untuk Memberdayakan Koperasi di Koppas dan Kopwan Jawa Timur. Disertasi tidak dipublikasikan. Malang: PPS UM.

Nugroho, B.A. 2005. Strategi Jitu Memilih Metode Statistik Penelitian dengan SPSS. Yogyakarta: Penerbit ANDI.

Prakash, Daman. 2008. Management Capacity Building for Strengthening Coopeative Enterprises. IFFCO Foundation, New Delhi.

Robbins, Stephen P. 2003. Perilaku Organisasi. Jilid 1. Terjemahan. Tim Indeks. Jakarta:PT INDEKS Kelompok GRAMEDIA.

Salim Al Idrus. 2008. Manajemen Koperasi: Teori dan Penerapannya. Tulungagung: Penerbit Cahaya Abadi. 
Samsuri. 2005. Daya Hidup Koperasi dan Implikasinya terhadap Kesejabteraan Anggota (Studi Kasus pada Koperasi Perternakan Bandung Selatan Pangalengan Jawa Barat). Disertasi tidak dipublikasikan. Bandung: Program Pascasarjana Universitas Pendidikan Indonesia Bandung. (Online), (http://digilib.upi.edu/union/ index.php/record/view/4021, Diakses 31 Oktober 2007).

Samsuri. 2005. Daya Hidup Koperasi dan Implikasinya terhadap Kesejabteraan Anggota (Studi Kasus pada Koperasi Perternakan Bandung Selatan Pangalengan Jawa Barat). Disertasi tidak dipublikasikan. Bandung: Program Pascasarjana Universitas Pendidikan Indonesia Bandung. (Online), (http://digilib.upi.edu/union/ index.php/record/ view/4021, Diakses 31 Oktober 2007).

Setiawan, Nugraha. 2005. Kajian Dinamika Organisasi pada Koperasi Peternakan. Penelitian. Bandung: Universitas Padjadjaran.

Siswoyo, Bambang Banu. 2004. Perilaku Organisasional Anggota Koperasi dan Pengarubnya terhadap Partisipasi Anggota serta Manfaat yang Diperoleh Anggota Koperasi. Disertasi tidak dipublikaiskan. Malang: PPS Unversitas Brawijaya Malang.

Sugiyono. 2004. Metode Penelitian Bisnis. Bandung: Alfabeta.

Syarif, T. 2002. Koperasi Menuju Budaya yang Berdaya Saing. Infokop, (Online), (http://www.smecda.com/deputi7/ file_Infokop/kop_menuju_budaya.htm, diakses 24 Pebruari 2008).

Syufri, A. 2005. Pendekatan Partisipatif dalam Penyuluban Pembangunan. (Online), (http://sumbar.litbang.deptan.go.id/ hln16122005_as.htm, diakses 24 Agustus 2007).

Tojjib, M. 2005. Tantangan Model Partisipasi, (Online), (http:// menkslek.tripod.com/, diakses 24 Agustus 2007).

Undang-Undang Dasar Negara Republik Indonesia tahun 1945.

Undang-Undang Sistem Pendidikan Nasional nomor 20 tahun 2003. Zeuli, Kimberly A. dan Robert Cropp. 1980. Cooperatives: Principles and Practices in The $21^{\text {st }}$ Century. USA: Universitas of Wisconsin Extension Publishing. 